\title{
Mg-RICH SMECTITE “PRECURSOR” PHASE IN THE TAGUS BASIN, SPAIN
}

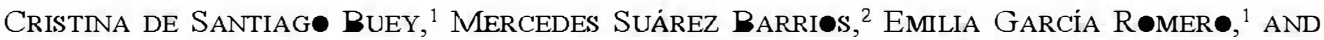

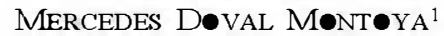

${ }^{1}$ Departamento de Cristalografia y Mineralogía, Facultad de Ciencias Geológicas, UCM, Spain

${ }^{2}$ Deparmento de Geología, Area de Cris lografia y Mineralogía, Facultad de Ciencias, Universidad de Salamanca, Spain

\begin{abstract}
The pink clays from the Tagus basin, Spain, were characterized by X-ray difraction (XRD), infrared spectroscopy (IR), scarming electron microscopy (SEM), and ransmission electron microscopy (TEM). Chemical were ob ane by plasma emission spectroscopy and analytical electron microscopy (AEM), and specific surface and cation-exchange capacity were measure also. The data indicate that these pink clays are primarily stevensite. This Mg-rich smectite is characterize by poor crystallinity, a high degree of structural disorder, wioctahedral character (pure magnesian), a very low cation-exchange capacity, a very small cryst size (which generates an abnormally high specific surface area), and a deficiency of octahedral cations. On the basis of the very small crystal size, a large number of edge dislocations, the lack of periodicity (turbostratic) in the structure, and a cellular (spherical) texture observed by TEM, we consider this occurrence to be an early stage of crys millization. Unlike other precursor clay materials described in the literature, this clay is not an alteration of volcanic ash, but it was generated by precipitation from a Si- and Mg-saturated medium.
\end{abstract}

Key Words - Precursor Clay, Smectite, Stevensite, Tagus Basin (Spain), Incipient Crystallization.

\section{INTRODUCTION}

The Tagus basin is an intramontane basin located in the central Iberian Peninsula. The basin is partially filled by Tertiary sediments deposited within a complex system of alluvial fans. These sediments, distributed in a concentric pattern, are weathering products of igneous, metamorphic, and calcareous rocks from peripheral mountains. Detrital facies occur near the margins of the basin, and the core of the basin is mainly saline, with intermediate zones consisting of mudflat facies. The nature, distribution, and characteristics of the different facies were described by Bellanca et al. (1992), Calvo Sorando et al. (1989), Domínguez Díaz (1994), and others.

The objective of this work is to study the "pink clays", which occur as interlayered strata in the "Green Clays Unit" as defined by Brell et al. (1985). They form part of the mud-flat facies (transition zone of the alluvial-fans system). Previous mineralogical studies (Brell et al., 1985; Doval et al., 1985; García Romero et al., 1990; Domínguez Díaz, 1994) showed that the pink clays are mostly magnesian $2: 1$ phyllosilicates, similar to saponites belonging to the "Green Clays Unit". However, details of the mineralogy, microstructure, and physico-chemical properties are different from saponite. The mineralogy of the pink clays remains unclear although they have been studied by X-ray diffraction (XRD), infrared spectroscopy (IR), and optical microscopy Brell et al. (1985) described them as chlorite-smectite interstratified minerals. Conversely, García Romero (1988) and García Romero et al. $(1988,1990)$ called them pure stevensite. Martín de Vidales et al. (1988) showed that they are composed of pure magnesian 2:1 phyllosilicates of "intermediate character" between end-member kerolite and a Mg-rich smectite phase. On the other hand, Martín de Vidales et al. (1991) and Cuevas (1991) suggested that the same clays were composed of kerolite-stevensite interstratifications with variable stevensite content. Pozo et al. $(1992,1996)$ and Pozo and Casas (1995) agreed that the clays contained kerolite-stevensite interstratified minerals. This paper provides the first ransmission electron microscopic (TEM) observations of these materials to better define the minerals present.

\section{MATERIAL AND METHODS}

Sampling was performed in three profiles: at Magán, Esquivias, and Valdemoro villages (Figure 1) where pink clays are interlayered between green saponitic clay layers. In general, the "Green Clays Unit" is $8-10 \mathrm{~m}$ thick and is composed of massive or bioturbate green or greenish-grey clays with intercalations of fining-upwards micaceous sands showing a thin parallel lamination. These green clays, which are mined commercially as bentonites, are mainly composed of phyllosilicates with minor feldspar and quartz. Most of these phyllosilicates (75-90\%) are saponites with $<1 \bullet \%$ illite (García Romero et al. 1988, 1990; Santiago Buey et al., 1998).

The interlayered pink-clay strata decrease in total thickness from $1.5-2 \mathrm{~m}$ in the Esquivias and Valdemoro zones to a few centimeters in the south of the basin (Magán). They usually appear as massive beds, with interlayered carbonates of little lateral continuity 


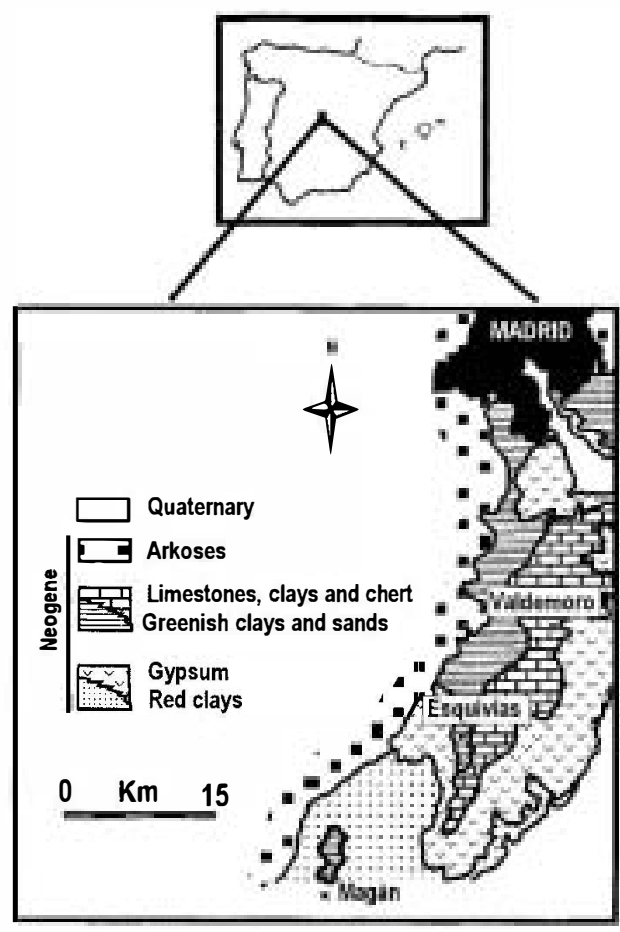

Figure 1. Map showing the geographic

and become more abundar
ero et al., 1988, 1990).

\section{Methodology}

Mineralogical identification was performed by XRD in a Philips 1130/90 diffractometer using CuK $\boldsymbol{\alpha}$ radiation and a graphite monochromator. Random powders were scanned from 2 to $65^{\circ} 20$ at a $0.16^{\circ} 20 / \mathrm{s}$ scan speed and oriented aggregates $(<2-\mu \mathrm{m}$ size fraction) were scanned from 2 to $18^{\circ} 2 \theta$ at a $0.33{ }^{\circ} 20 / \mathrm{s}$ scan speed

IR absorption spectra were obtained on a BIO RAD SPC 3200 instrument, using the $\mathrm{KBr}$ pellet technique from 4000 to $500 \mathrm{~cm}^{-1}$. Elemental analyses were performed by plasma emission spectroscopy, using a Perkin-Elmer emission spectrometer, model Plasma II. Previous to the analysis, solids were digested under pressure in a nitric-hydrofluoric acid mixture, contained in a polytetrafluoroethylene (PTFE) autoclave. Additional elemental X-ray microanalyses from isolated particles were obtained by analytical electron microscopy (AEM).

Information about the oxidation states of the iron was obtained by Mössbauer spectroscopy. Room-temperature $(291 \pm 1 \mathrm{~K})$ absorption spectra were obtained with Mössbauer "Perseus" spectrometer of Russian origin. In this spectrometer, the stabilization and the control of vibrator velocity are obtained via laser in-
Pink clays

Green clays (high content of saponite)

sand levels

carbonate levels \# Massive = Parallel lamination $\angle$ Trough cross bedding $\triangle$ Fining-up sequence $\wedge$ Gradual transition \& Sepiolite nodules 55 Bioturbation (a) Fossils 4 SAMPLING

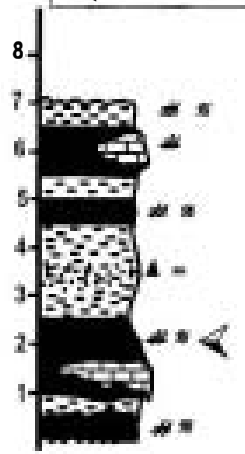

ESQUIVIAS

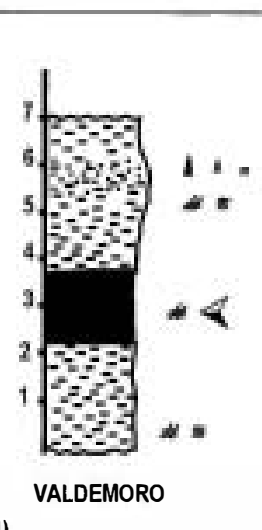

(Martin de Vidales et al., 1991)

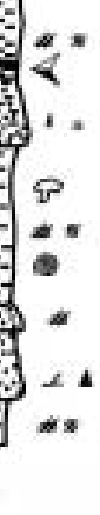

1988)

material.

terferometer. A source of ${ }^{57} \mathrm{Co}$ in a $\mathrm{Cr}$ matrix was used. The spectra were measured in the velocity interval \pm $\mathrm{mm} / \mathrm{s}^{-1}$.

Particle morphology and texture were observed by scanning electron microscopy (SEM). SEM observations were performed with a JEOL JSM6400 operated at $20 \mathrm{kV}$ and equipped with a Link eXL X-ray energy dispersive detector. Samples were air-dried and then oven-dried at $40-60^{\circ} \mathrm{C}$ until constant weight. Finally, and prior to observation, they were lightly coated with gold.

TEM studies were performed with undisturbed specimens that presumably retain original textures. Oriented sections were prepared according to the method of Tessier (1984) which minimizes dehydration during TEM observation. The resulting epoxyclay complexes are sectioned by ultramicrotomy (50 $\mathrm{nm}$ thick). The TEM observations were performed in a JEM 2000FX microscope operated at $200 \mathrm{kV}$ and equipped with a Link AN10000 X-ray energy dispersive detector.

The exchange cations were extracted with $\mathrm{NH}_{4}{ }^{+}$and the cation-exchange capacity (CEC) was calculated using distillation and measurement of $\mathrm{NH}_{4}{ }^{+}$by the Kjeldaljh method, without removing soluble salts (Santos, 1979). The specific surface area was determined from a Micrometritics ASAP 2010 analyzer, after outgassing the sample at $110^{\circ} \mathrm{C}$ for $8 \mathrm{~h}$ to a residual pressure 


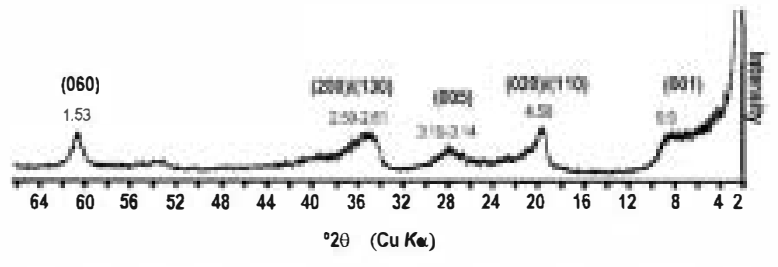

Figure 2. Representative XRD powder pattern of the pink clays.

of $10^{-5} \mathrm{~mm} \mathrm{Hg}$. The Brunauer-Emmett-Teller (BET) method was used for the calculation (Brunauer et al., 1938).

\section{RESULTS AND DISCUSSION}

Figure 2 shows a representative XRD pattern where a very broad diffraction effect at low angles can be seen. This effect was also described by Martín de Vidales et al. (1991). These authors assumed this phenomenon is related to particle-size and textural features (i.e., stacking disorder). This XRD powder pattern is composed of $(\boldsymbol{h} k 0)$ and $(00 l)$ broad and asymmetrical bands instead of discrete reflections, which may be related to the lack of three-dimensional periodicity because of random rotations or translations between layers, giving rise to extensive stacking disorder. Also, partial hydration of the sample can produce broadening of the basal reflections. The $b$-axis dimension estimated from the (060) reflection is $9.18 \AA$, which indicates the material is trioctahedral. No nonclay minerals were detected.

Figure 3 shows a representative X-ray diffraction pattern of the oriented clay aggregate of $<2 \mu \mathrm{m}$ (airdried, glycolated, and heated). Low-angle scattering $\left(\leq 8.8^{\circ} 2 \theta\right)$ is observed in all the cases. This band may be produced by different interlayer materials in the sample. Samples solvated with ethylene glycol swell slightly. Also, when heated at $550^{\circ} \mathrm{C}$, the spacings collapse slightly. These phenomena are observed by the displacement of the band towards lower or higher angles, respectively. The 002 and higher peaks are missing in the pattern indicating the lack of periodic stacking of layers along the [001] direction. The absence of a well defined 001 reflection makes it impossible to calculate a crystallinity index or mean crystal size. Although the smectitic nature of the clays and the trioctahedral character of the mineral can be determined by XRD, the broad reflections (Martín de Vidales et al., 1991 ) suggest that these materials have limited coherent domains with a very small number of layers per particle (i.e., poor crystallinity or high structural disorder).

The IR data show intense and complex OH-stretching bands (4000-3000 $\mathrm{cm}^{-1}$ ) owing to hydroxyl groups and $\mathrm{H}_{2} \mathrm{O}$ molecules (Figure 4). These bands indicate a large amount of $\mathrm{H}_{2} \mathrm{O}$ associated in different ways with the structure, as is typical for minerals of

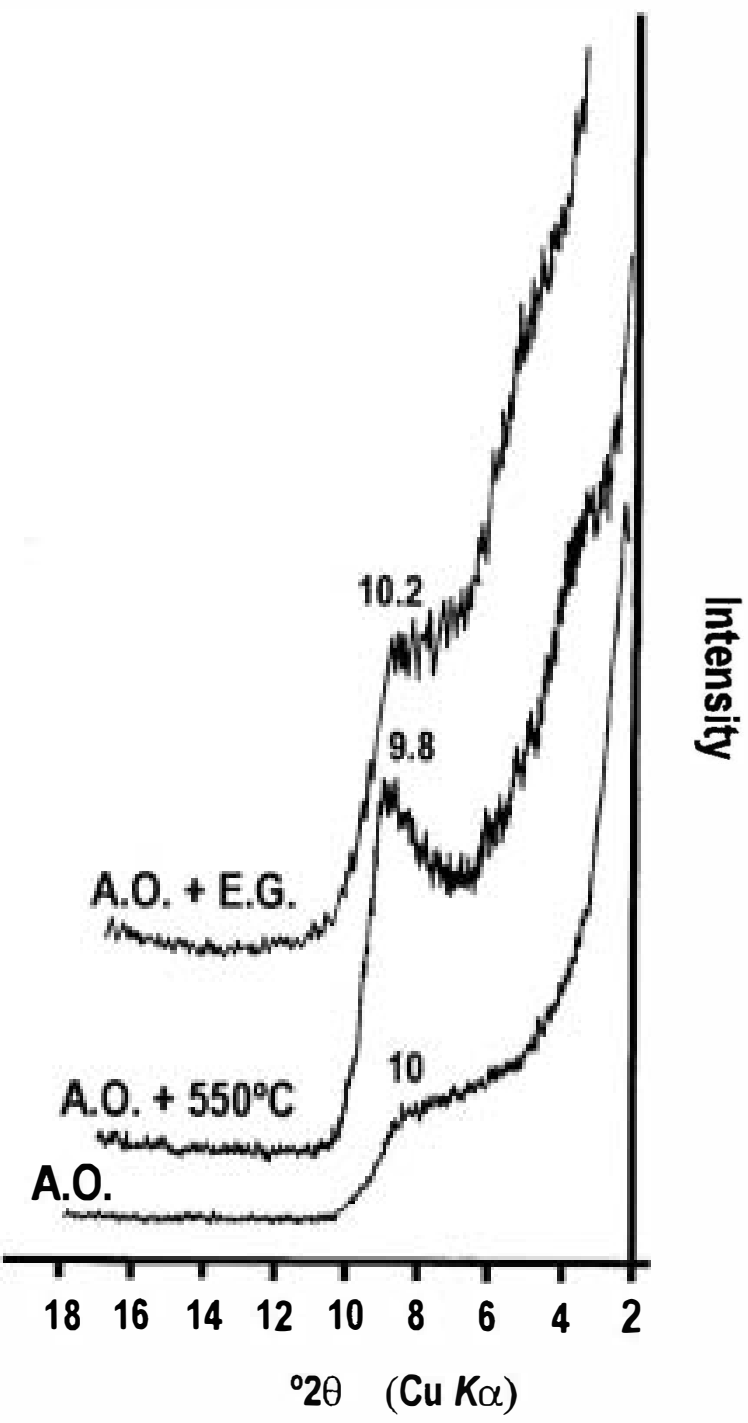

Figure 3. Representative XRD pattern of the oriented aggregate of clay fraction $<2 \mu \mathrm{m}$. Air-dried (O.A.), glycolated (O.A. + EG), and heated (O.A. $\left.+550^{\circ} \mathrm{C}\right)$.

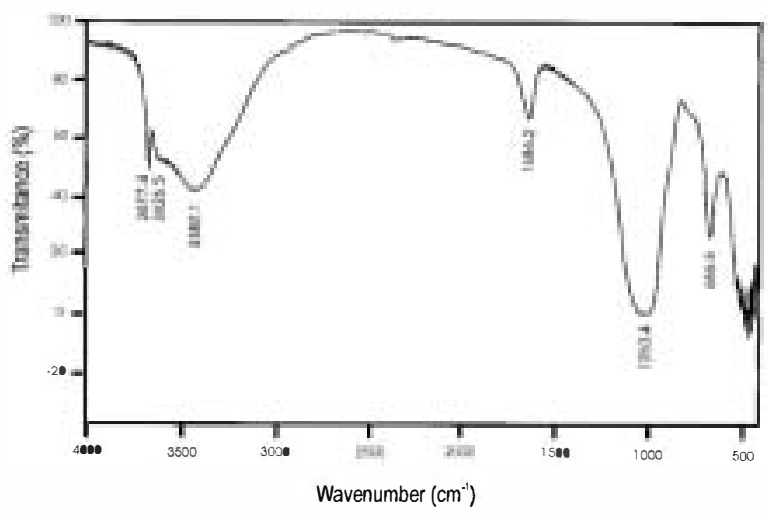

Figure 4. IR spectrum of the pink clays. 
Table 1. Whole-rock chemical analyses of saponite, sepiolite, two stevensites, a saponite from the Tagus basin, and from pink clay material studied here.

\begin{tabular}{|c|c|c|c|c|c|c|}
\hline Oxide & Saponite $^{1}$ & Saponite $^{2}$ & Sepiolite $^{3}$ & Stevensite $^{4}$ & Stevensite $^{5}$ & This study ${ }^{6}$ \\
\hline $\mathrm{Si}_{2}$ & 48.96 & 55.60 & 54.56 & 57.30 & 57.24 & $55.03 \pm 2$ \\
\hline Ti॰ & 0.20 & 0.62 & - & - & - & $0.07 \pm 0.0005$ \\
\hline $\mathrm{Al}_{2} \mathbf{\vartheta}_{3}$ & 7.30 & 13.52 & 0.99 & - & - & $2.13 \pm 0.01$ \\
\hline $\mathrm{Fe}_{2} \mathrm{O}_{3}$ & 11.93 & 3.63 & 1.56 & 0.32 & 1.14 & $0.94 \pm 0.003$ \\
\hline $\mathrm{Fe}$ & 1.24 & 0.91 & 0.88 & - & 0.12 & $0.24 \pm 0.003$ \\
\hline $\mathrm{Mn} \bullet$ & - & 0.04 & 3.02 & 0.21 & 0.75 & $0.01 \pm 0.0001$ \\
\hline $\mathrm{Mg} \bullet$ & 23.39 & 21.58 & 21.72 & 27.47 & 27.89 & $24.01 \pm 0.2$ \\
\hline $\mathrm{Ca}$ & 2.42 & 0.93 & 0.00 & 0.97 & 0.38 & $0.01 \pm 0.004$ \\
\hline $\mathrm{Na}_{2} \bullet$ & 0.04 & 0.78 & 0.01 & 0.03 & - & $0.03 \pm 0.003$ \\
\hline $\mathrm{K}_{2} \bullet$ & 0.06 & 2.30 & 0.02 & 0.03 & - & $0.04 \pm 0.01$ \\
\hline $\mathrm{H}_{2} \bullet(+)$ & - & 12 & 9.23 & 6.69 & 7.69 & 16.32 \\
\hline $\mathrm{H}_{2} \bullet(-)$ & 4.45 & - & 7.92 & 7.17 & 4.76 & - \\
\hline
\end{tabular}

${ }^{1}$ Winnweiler, Pflaz, Germany (Quakernaat, 1970).

${ }^{2}$ Tagus basin, Spain (Santiago Buey et al., 1998).

${ }^{3}$ Akatani Mine (Otsuka et al., 1966).

${ }^{4}$ Springfield (Faust and Murata, 1953).

${ }^{5}$ Jersey City (Faust and Murata, 1953)

${ }^{6}$ Tagus basin, Spain (This paper, pink clays).

the smectite group. The spectrum in the $\mathrm{OH}$ region of the unheated material shows a sharp absorption band at $3677 \mathrm{~cm}^{-1}$ and a broad band at $3382 \mathrm{~cm}^{-1}$ with a shoulder at $3626 \mathrm{~cm}^{-1}$. The absorption band at 3677 $\mathrm{cm}^{-1}$ is assigned to the $\mathrm{OH}$-stretching vibration in purely magnesian octahedral sheets (OH-Mg-Mg) (Farmer, 1974; Van der Marel, 1976). The broad bands at 3626 and $3382 \mathrm{~cm}^{-1}$ are attributed to the $\mathrm{OH}$ stretching vibration of interlayer and hygroscopic $\mathrm{H}_{2} \mathrm{O}$, respectively. Absorption corresponding to the bending vibration of $\mathrm{H}_{2} \mathrm{O}$ molecules (atmospheric moisture) occurs at $1636 \mathrm{~cm}^{-1}$ as a single band. In the lower frequency region from 700 to $1200 \mathrm{~cm}^{-1}$, the $\mathrm{Si}-\mathrm{O}$ stretching absorption appears at $\sim 1050 \mathrm{~cm}^{-1}$ as a strong and broad band, which is common to silicates (Faust et al., 1959). In addition to this band, the Si$\mathrm{O}-\mathrm{Mg}$ bending band at $666 \mathrm{~cm}^{-1}$ was observed. From the smectite group, stevensite is the only mineral which exhibits this absorption band, but it is typical of talc and sepiolite as well (Faust et al., 1959).

The OH-Mg-Mg stretching band at $3677 \mathrm{~cm}^{-1}$ and the $\mathrm{Si}-\mathrm{O}-\mathrm{Mg}$ bending band at $666 \mathrm{~cm}^{-1}$ are related to $\mathrm{Mg}$ in the octahedral sheet and correspond to a pure magnesian smectite, sepiolite, or talc (Farmer, 1974; Van der Marel, 1976). The total absence of Al-related bands at 919-915 cm-1 (Al-Al-OH) and $527-517 \mathrm{~cm}^{-1}$ (Si-O-Al) (Madejova et al., 1992; Vicente-Rodríguez et al., 1996) suggests the absence or near absence of saponite.

Chemical analyses obtained by plasma spectroscopy are summarized in Table 1. For comparison, selected analyses from the literature are presented also. The pink clays studied in this work have a lower $\mathrm{Mg}$ content than talc and kerolite and higher Al content than other stevensites.
Because the XRD data indicate that this material is a nearly pure 2:1 phyllosilicate, the structural formula was calculated based on $\mathrm{O}_{20}(\mathrm{OH})_{4}$ as: $\mathrm{Si}_{\mathbf{8} 01} \mathrm{O}_{20}\left(\mathrm{Al}^{3+}{ }_{36}\right.$

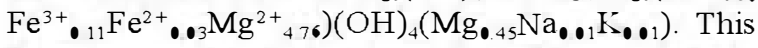
formula corresponds to stevensite with an extremely low CEC (generated by a deficiency of octahedral cations in the structure, and not by isomorphous substitutions) or an interstratified clay. The latter possibility agrees with Martín de Vidales et al. (1991), Cuevas (1991), Pozo et al. (1992, 1996), and Pozo and Casas (1995).

Because the whole-rock chemical analysis corresponds to the entire sample and it is not possible to exclude contamination by impurities not detected by $\mathrm{XRD}, \mathrm{AEM}$ analyses were performed on 68 isolated particles to determine the distribution of elements between grains. Some heterogeneity of $\mathrm{Si}, \mathrm{Mg}, \mathrm{Al}$, and $\mathrm{Fe}$ is observed between individual particles, indicating a mixture of different minerals. Most of the analyses $(\sim 85 \%)$ correspond to stevensite with a negligible amount of aluminum in the terahedral sheet and a deficiency of atoms $(<6)$ in octahedral coordination (Faust et al., 1959). In addition, talc $(\sim 1 \bullet \%)$ and saponite $(\sim 5 \%)$ particles were found. Chemical analyses in wt. $\%$ for the purest particles of each of the three minerals are listed in Table 2

The presence of muscovite $(<1 \%)$ and saponite $(\sim 5 \%)$ generates most of the Al detected by plasma spectroscopy in the whole rock. Some particles were found with an anomalously high quantity of $\mathrm{SiO}_{2}$ or $\mathrm{MgO}$ as detected by AEM. This may be caused by $\mathrm{SiO}_{2}$ or $\mathrm{Mg}$ adsorbed on the surface of the particles (Jones, 1985) or by $\mathrm{SiO}_{2}$ and $\mathrm{MgO}$ as a coating.

Isolated particle analyses are represented in Figure 5. For comparison, the theoretical fields of trioctahed- 
Table 2. Chemical analyses in wt. \% for the purest particles of stevensite, talc, and saponite found in the pink clays.

\begin{tabular}{lccc}
\hline Oxide & Stevensite & Talc & Saponite \\
\hline $\mathrm{SiO}_{2}$ & 64.73 & 63.05 & 53.77 \\
$\mathrm{TiO}_{2}$ & - & - & - \\
$\mathrm{Al}_{2} \mathrm{O}_{3}$ & 3.15 & - & 15.46 \\
$\mathrm{Fe}_{2} \mathrm{O}_{3}$ & 2.11 & - & 6.51 \\
$\mathrm{FeO}$ & 0.52 & 36.94 & 1.63 \\
$\mathrm{MnO}$ & - & - & - \\
$\mathrm{MgO}$ & 24.68 & - & 15.48 \\
$\mathrm{CaO}$ & 1.58 & - & 2.63 \\
$\mathrm{Na}_{2} \mathrm{O}$ & 1.84 & - & 1.76 \\
$\mathrm{~K}_{2} \mathrm{O}$ & 1.38 & & 2.76 \\
\hline
\end{tabular}

ral phyllosilicate minerals are given also. The grains cluster in or near the theoretical compositions of talc, stevensite, and saponite, respectively. Although some particles have sepiolite composition, no fibrous particles were observed.

The CEC of the pink clays in $23 \mathrm{meq} / 100 \mathrm{~g}$. This exchange capacity is very low with respect to most smectites, but is in accordance with other determinations for stevensite. For example, Faust et al. (1959) reported an exchange capacity of $37.6 \mathrm{meq} / 100 \mathrm{~g}$ and Tettenhorst and Moore (1978) reported $30 \mathrm{meq} / 100 \mathrm{~g}$ for the stevensites they studied. Partly in recognition of a low CEC, Faust and Murata (1953) defined stevensite as a mineral of the montmorillonite group, with a low CEC arising from a deficiency in octahedral cations rather than from other isomorphous substitutions. The main exchangeable cations are $\mathrm{Mg}$ (10.4 meq/100 g), $\mathrm{Ca}(9.8 \mathrm{meq} / 100 \mathrm{~g}), \mathrm{Na}(1 \mathrm{meq} / 100 \mathrm{~g})$, and $\mathrm{K}(0.4$ $\mathrm{meq} / \mathrm{lo0g})$.

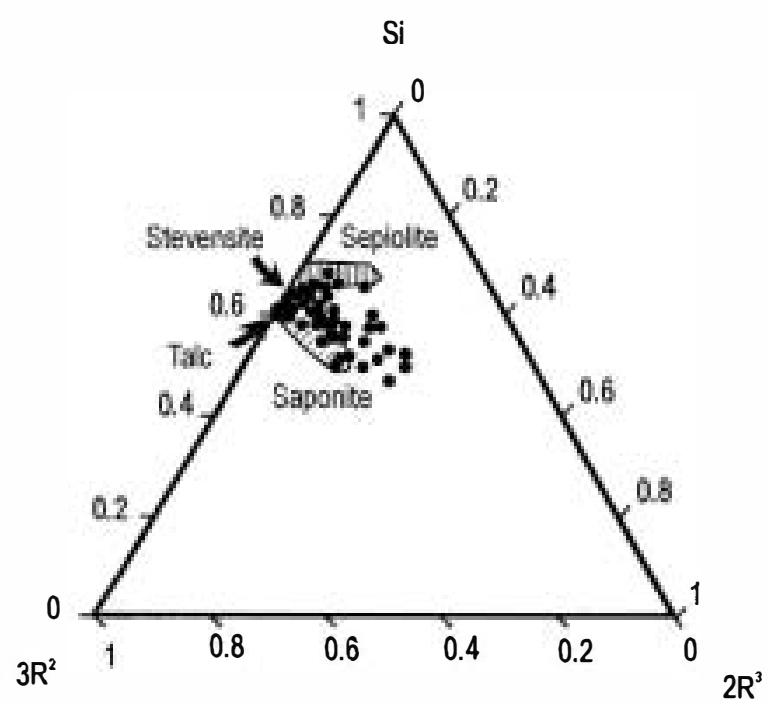

Figure 5. Ternary $\mathrm{Si}-3 \mathrm{R}^{2}-2 \mathrm{R}^{3}$ diagram of analyses obtained by analytical electron microscopy and showing the theoretical field for trioctahedral minerals $3 \mathrm{R}^{2}=\left[\left(\mathrm{Mg}^{2+}+\mathrm{Fe}^{2+}\right) / 3\right], 2 \mathrm{R}^{3}$ $=\left[\left(\mathrm{Al}^{3+}+\mathrm{Fe}^{3+}\right)-\left(\mathrm{Na}^{+}+\mathrm{K}^{+}+2 \mathrm{Ca}^{2+}\right)\right] / 2$ (after Velde, 1985).
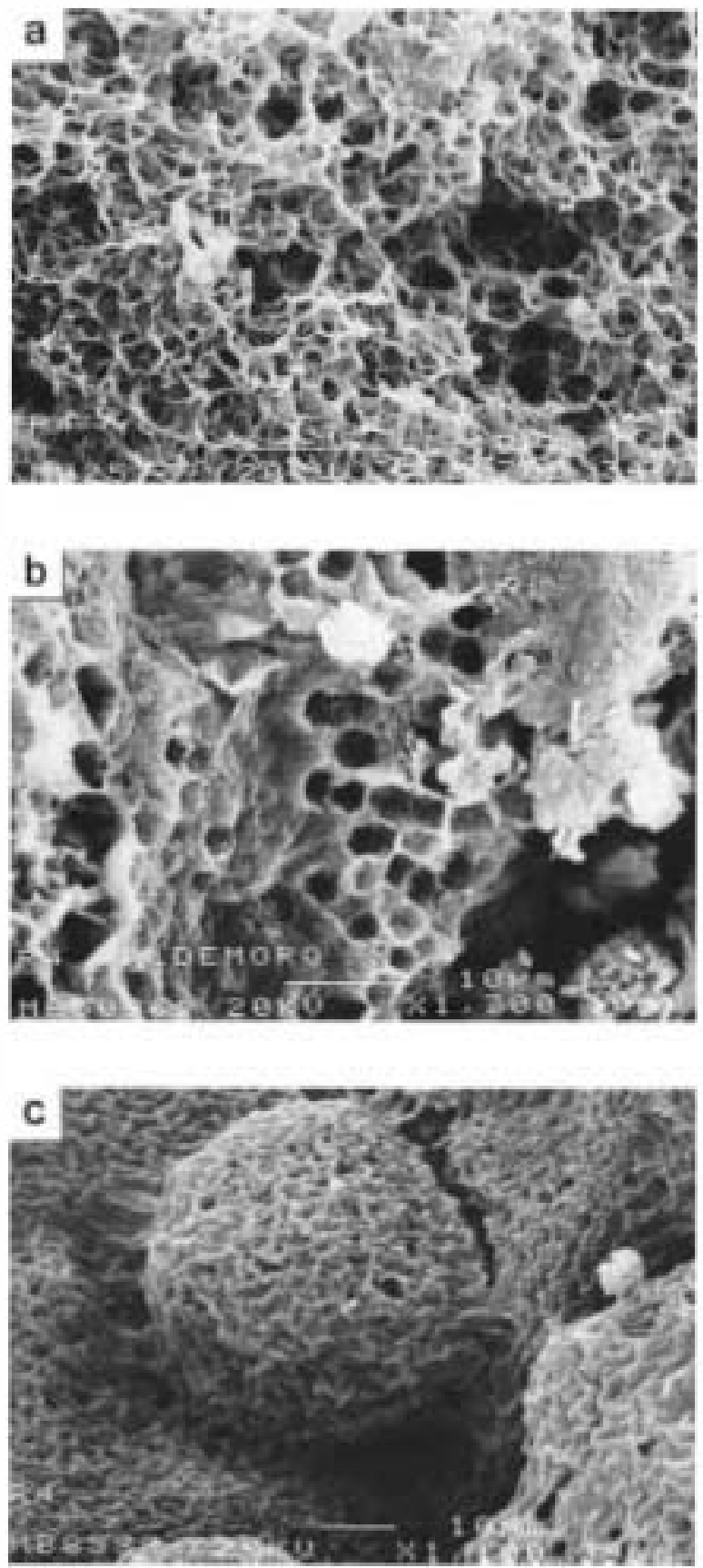

Figure 6. a) Random array of smectite particles (honeycomb microstructure). b) Edge-to-edge and edge-to-face contacts between particles. c) Spherical aggregates of particles.

The specific-surface area obtained $\left(\mathrm{N}_{2}\right.$ - $\left.\mathrm{BET}\right)$ is high (392 $\mathrm{m}^{2} / \mathrm{g}$ ) owing to external surfaces of the particles $\left(314 \mathrm{~m}^{2}\right)$, and the remaining area $\left(78 \mathrm{~m}^{2}\right)$ corresponds to internal (interlayer) surfaces. Thus, an extremely small crystallite size is deduced, in agreement with incipient crystal growth.

In general, a nearly isotropic fabric is observed, formed by a random (non-oriented) array of very small 

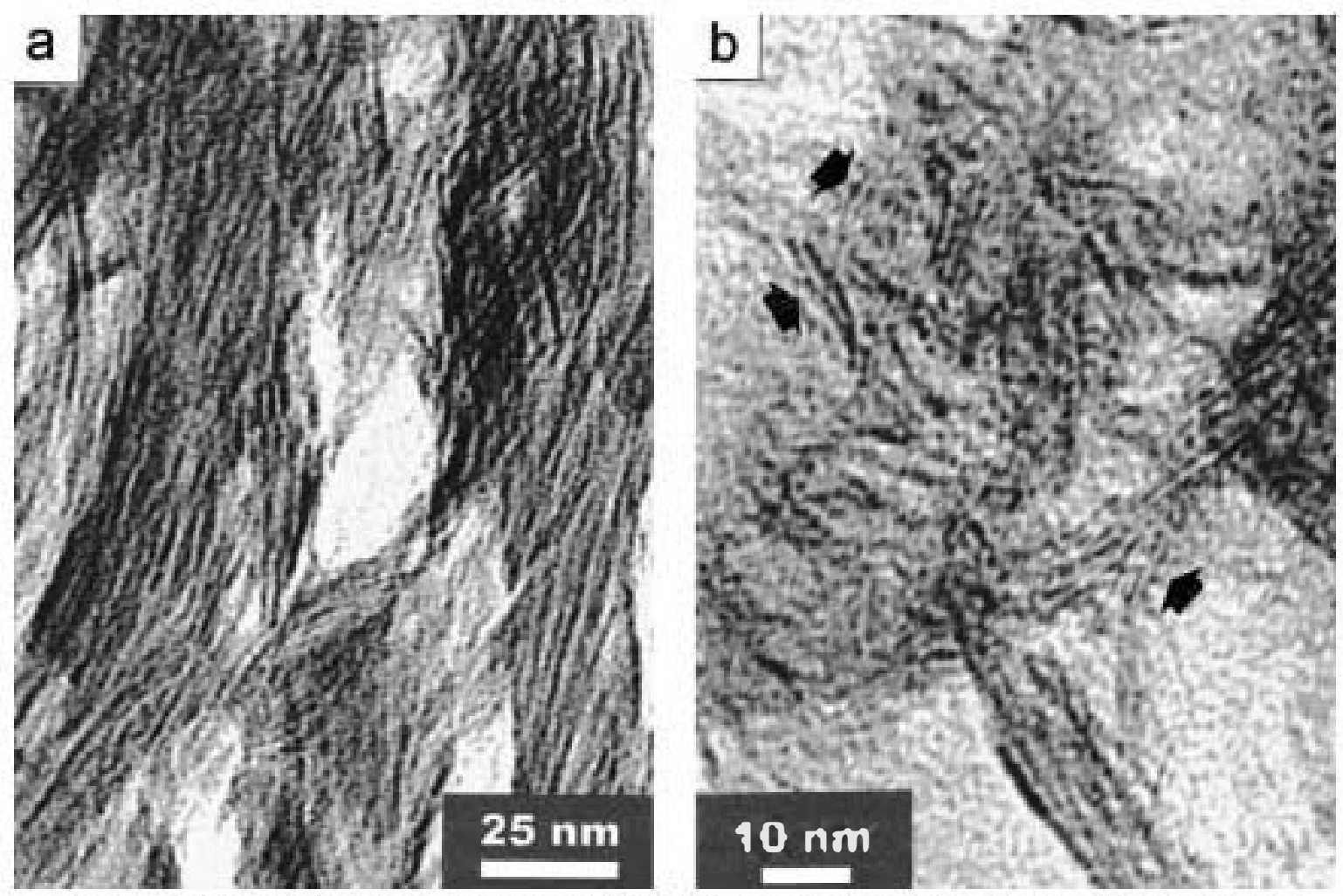

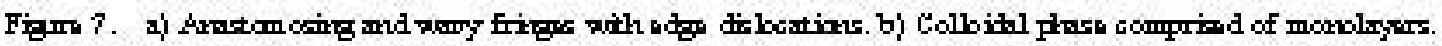

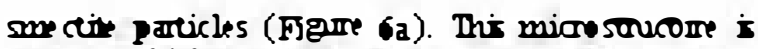
typir al of righ-sopelling soit with high sal concertratims that reduce icerpaticle Iepulsion (Betmeta and Hulber, 1986; $\tan$ Obhen, 1966). Aclost samples have oen soncorres with proudopolgmal voids ("comflake" and "homencomb " microsturorre) forme d of som cir lominar particles, which ke ep edor-taface and eds-to-edgr contacts the latter are more athmdent) (Figre o). This usctre esplains the very lews

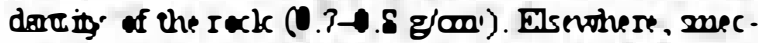
tie particles show a indengy to be coronected by fecoming flecs or age git structures with spierical

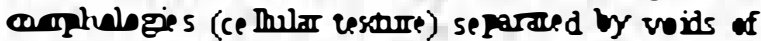
varing sires and stapes (Figre (c).

TElud mic ogeghs show broad, poerly de fined fringes varjing frem 10 it 18 í. thick. The particles hase wavy, anaramsiritg, and discoromons laticefring imgs (Figre $7 a$ and 3b) with a high romile of edge dislocations and clengers in image comorat alorig the layers, owing to small oriesterion changes in the orcal (Bantie id and Eggiton, 1988). The tarer 08 ne ity and way soncorre of the hetice frires 5 are consisent with sample f comati in in relicively sha Dow war I ersir crontes whe re arsaltixation eccurred relacively rapidly at bow vomeratires.

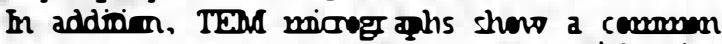
sencerre of hoDowo-packed spheres (Figre 8) havivg dpparent dismeters ranging from 50 is $1000 \mathrm{~A}$. Some
Shere walls diplay a concertic lasered soncarte. This cellular ve sare sesembles de scritivins of priver. tise clay precursers forming frem glarses, ort, ar we athering of pre vinus minerals. For e sample, Egry. ton and Buselik (1981) sudied precursars of smectite in the alsracion of $\mathrm{K}$-rich feldsar. Dury foumd a celhubr ventre of packed hallowosher es with mater lay. ered concenerically arement the bubbles. Drey peras.

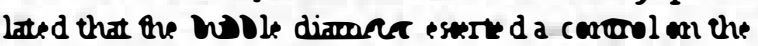
rate of opsalliarion of the bulble walls. Later, Eg-

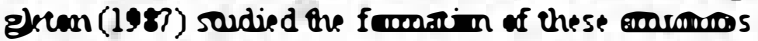
in the crosallia aim process of chy minerat fram

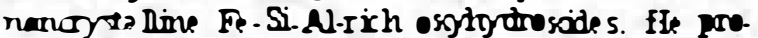
pored that the layer structure witing the walt of the wubles indicates incipient developeore ort of crsals. Ta alki and Fyfe (1987) and Ta alki $\in$ al (1989) ob. ser sred well-cordered domains with she rical stuctures. Dury conchuded also that the sonvomes were eatly sages of crsallisaion within volcanic glass, and mont be prec urs ars from which clay deve bps. Masuda es al (1996) soudied a precinser as an intermediate stage int the forotion of athigenic monectite from volcarix ghss. Forodno es al. (1993) escomined the formaim processes of clay minerat by tranf monsin

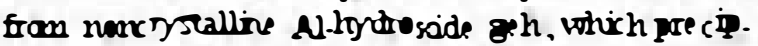
inted frem solvtions in eart be thering of vol: dric glass, leadiug o oralline maxtia 5 . 


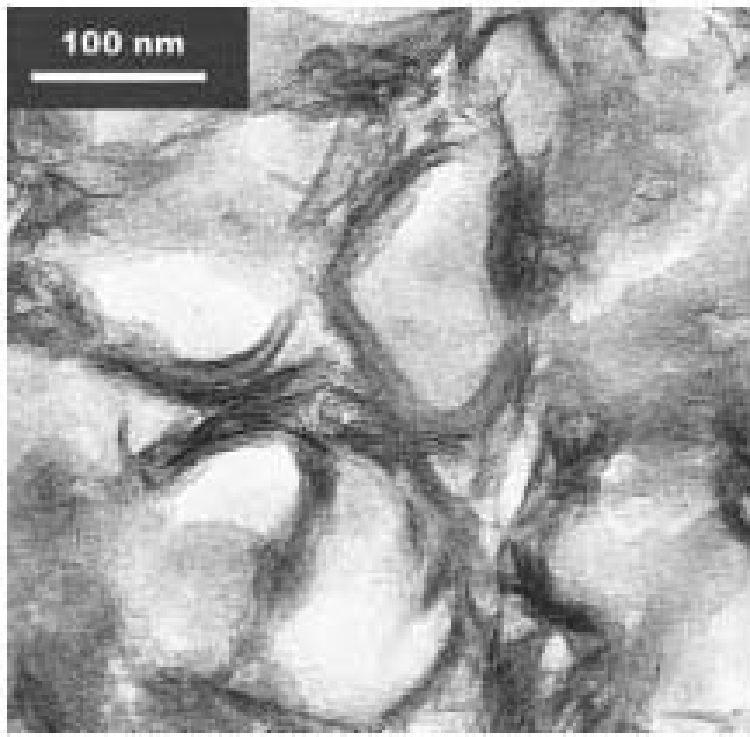

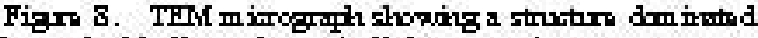

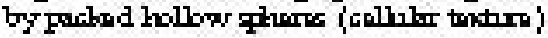

These pevions serdies, in agree want with onr ob-

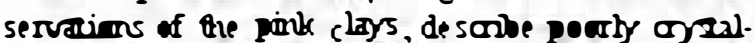
line paricles with tesontres of hollow-packed ghlires. The wall matrial of these pheres corcains peorly corsalliged mator which way do se lop

chy minerah. These particles are referred to here as "Mre aIIjer-CIay material" and are inferred to be inc ine reacle aim sites of very fine-gr amed. som citr- like Iegions. Thes Iegions have cellhalar te stare, a high density of edge dislocations, and very mall crysallits size 5.

The ce thular reschre desarbed in this work is not inherited from volcanix a sh The diringuisting entre of tovs pinte clay is re hed $v$ its sedimeneary $a$ in. There is no possibility of volcanic influence in it for. marion and. therefore, there is no prevines tesome which $c$ an be ithelite d. The sedine stary arigin of this chy by precipitation in an intrecotivental l basin is we ll bonown (Belbnca of a!. 1992; Bre Il et al., 1985; Cakro Surando at. 1989; Deconger Dfar, 1994; Garc fa Romero, 1988; Garcla Romerro et al. 1990) and, as $\mathrm{f}$ al as we are a war, this is the first time this cellular tesorre is obsersed teriat.

\section{CONCLUSIONS}

Dhe characurisation of the pinte clays from the Th. ges basm, Sam, was accomplithed by several sechniques of which the TElal obses sations were the most iomprare TEMa calti indicar that the presence of a

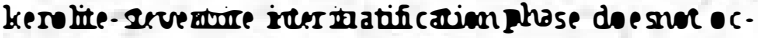
CUr as presious authers have arge d by using DR. IR and optix al mirroscopy cattl (Maren de Vhdales et al. 1988, 199 li arvas, 1991 ; Poas et al. 1992, 1996;
Poas and Casas, 1995). In comat ont vins is that this marerial is composed of alomest pure Mg-rich

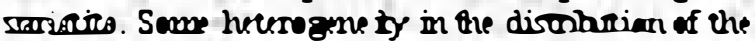
majer elacinar betheen Particles, and the corse que rt

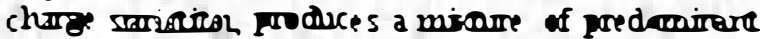
suvensite paricles with small anromot of spenite and tale particles.

pinte clays are mainty canposed of secomsite sheno. ing the follenoing poperties: a variable $>10 . \hat{\Lambda}$ iterlayer spacing, and the byer chare arises frem a deficimoy in ectahedral cations rather then from carion substintions (in ageement with Faust and Morrata, 1953; and Faus et al., 959). Finthemmore, the re is inthomore ne ity in the requence of ligers 5 which makes

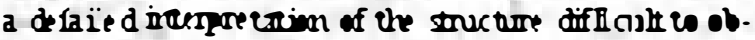
tain (Eindky, 1955). Hondever. TEDad obscration

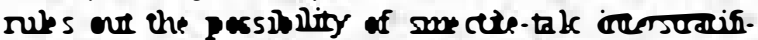
carion. Ther is no welt developed lajer stacking and there i no ahponsiom of spacings along the stecking

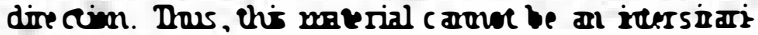
fied mineral

The bounday between kerolite, dpar oscimate by:

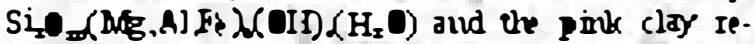

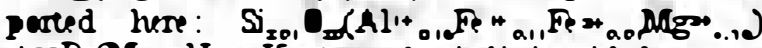

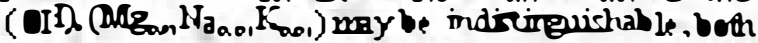
becasse the chrowistios are close and an accurate chemix al devmination is dificult. JaRD and IR data are ree dizgnostix. We cortiom the smectitix nume of the pink clays by means of is swelling porercial as obser sred by

\section{A KSNOWLEDGNAOTIS}

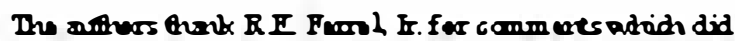
murah es inprew boch to focm andthe catent of tris powr.

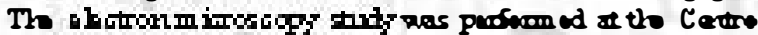

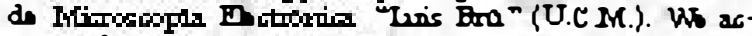

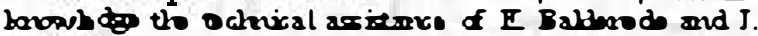
Gaxmb.

\section{TEFTENCES}

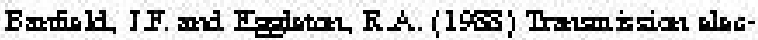

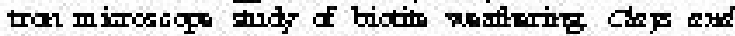
Cay ation rals $36,47-60$.

Bollnci, A Cabo, JP, Consi, P, Heri, R, and Pow, ML

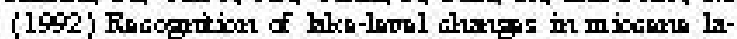
outrix unde, Mratrid bain, Spain. Hidenes fram facis

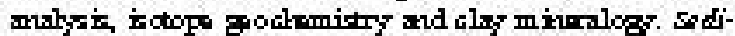
montry solog, 76, 135-103.

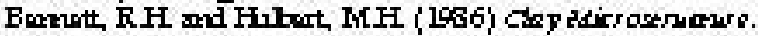
D. Rridel Publidizg, Botan, 161 pp.

Broll I M, Dov al, M, and Curmes, M. (1985) ckymimal ditritrian in the w apaitic Mficcen sodiments of the Tajo

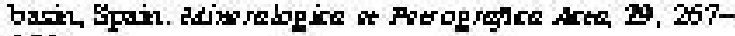
276.

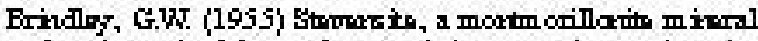

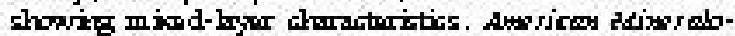
gist 40, $239-247$.

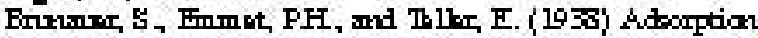

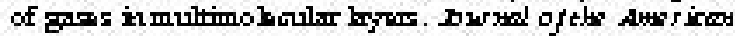
Chemiral sociney, 60, 309-319.

Cabo Sarado, IP, Abow Zxm, AM, and Garch del cum, M.A. (1089) Mbdk of miocme margival houtrive 
sedimentation in response to varied depositional regimes and source areas in the Madrid basin (central Spain). Pa-

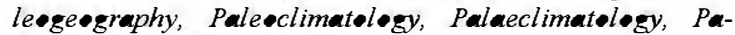
laevecel•gy, 70, 199-214.

Cuevas, J. (1991) Caracterización de las Esmectitas Magnésicas de la Cuenca de Madrid com॰ Material de Sellade. Alteración Hidretermal. ENRESA technical publication $n^{\bullet}$ $04 / 92$

Domínguez Diaz, M.C. (1994) Mineralogia y sedimentologia del neógeno del sector centro occidental de la cuenca del Tajo. Ph.D. thesis, Universidad Complutense de Madrid, Spain, $397 \mathrm{pp}$.

Doval, M., Dominguez Diaz, M.C., Brell, J.M., and Garcia Romero, E. (1985) Mineralogía y sedimentología de las facies distales del borde norte de la cuenca del Tajo. Beletín de la Seciedad Española de Mineralogia, 8, 257-269.

Eggleton, R.A. (1987) Non-crystalline Fe-Si-Al-oxyhydroxides. Clays and Clay Minerals, 35, 29-37.

Eggleton, R.A. and Buseck, D.R. (1980) High-resolution electron microscopy of feldspar weathering. Clays and Clay Minerals, 28, 173-178.

Farmer, V.C. (1974) The Infrared Spectra of Minerals. Mineralogical Society of Great Britain, London, $539 \mathrm{pp}$.

Faust, G.T. and Murata, K.J. (1953) Stevensite, redefined as a member of the montmorillonite group. American Mineral•gist, 38, 973-987

Faust, G.T., Hathaway, J.C., and Millot, G. (1959) A restudy of stevensite and allied minerals. American Mineral $\bullet$ gist, $44,342-370$

Garcia Romero, E. (1988) Estudio mineralogico y estratigráfico de las arcillas de las facies centrales del neógeno del borde sur de la cuenca del Tajo. Ph.D. thesis, Universidad Complutense de Madrid, Spain, $356 \mathrm{pp}$.

Garcia Romero, E., Brell, J., Doval, M., and Perruchot, A. (1988) Caracteristicas y evolución de la sedimentación neógena en la región de la Sagra (cuenca del Tajo). Beletín de la Real Seciedad Españela de Histeria Natural (Geølegia), 84, 85-99.

Garcla Romero, E., Brell, J.M., Doval, M., and Navarro, J.V. (1990) Caracterización mineralógica y estratigráfica de las formaciones neógenas del borde sur de la cuenca del Tajo (comarca de la Sagra). Bøletín Geølégic y Miner•, 101, 945-956

Jones, B.F. (1985) Clay Mineral Diagenesis in Lacustrine Sediments. U.S. Geological Survey Bulletin 1578, Washington, D.C., 291-300

Kawano, M., Tomita, K., and Shinohara, Y. (1997) Analytical electron microscopic study of the noncrystline products formed at early weathering stages of volcanic glass. Clays and Clay Minerals, 45, 440-447.

Madejová, J., Putyera, K., and Cicél, B. (1992) Proportion of central atoms in octahedra of smectites calculated from infrared spectra. Geolegica Carpathica, Clays, 2, 117-120.

Martin de Vidales, J.L., Pozo, M., Medina, J.A., and Leguey, S. (1988) Formación de sepiolita-paligorskita en litofacies lutítico-carbonáticas en el sector de Borox-Esquivias (Cuenca de Madrid). Estudies Geølégices, 44, 7-18.

Martin de Vidales, J.L., Pozo, M., Alia, J.M., García Navarro, F., and Rull, F. (1991) Kerolite-stevensite mixed-layers from the Madrid basin, central Spain. Clay Minerals, 26, 329-342.

Masuda, H., 'Neil, J.R., Jiang, W., and Peacor, D.R. (1996) Relation between interlayer composition of authigenic smectite, mineral assemblages, I/S reaction rate and fluid composition in silicic ash of the Nankai trough. Clays and Clay Minerals, 44, 443-459.

-tsuka, R., Imai, N., and Nishikawa, M. (1966) on the dehydration of sepiolite from the Akatani mine. Niigata prefecture, Japan. Joumal of the Chemical Søciety of Japan (Industrial Chemistry Seciety), 66, 1677-1680.

Pozo, M. and Casas, J. (1995) Distribución y caracterización de litofacies en el yacimiento de arcillas magnésicas de esquivias (neógeno de la cuenca de Madrid). Boletín Ge légic $y$ Minere, 106, 265-282.

Pozo, M., Casas, J., Moreno, A., and Medina, J.A. (1992) -rigin of sedimentary magnesium bentonites in marginal lacustrine deposits (Madrid basin, Spain). Chemical Geol•gy, 107, 457-461.

Pozo, M., Moreno, A., Casas, J., and Marmn Rubí, J.A. (1996) Estudio geoquimico de litofacies con arcillas magnésicas en depósitos lacustres-palustres de la cuenca de Madrid. Boletin de la Seciedad Española de Mineralogia, 19, $71-$ 83.

Quakernaat, J. (1970) A new occurrence of a macrocrystalline form of saponite. Clay Minerals, 8, 491-493.

Romero, R., Robert, M., Elsass, F, and Garcia, C. (1992) Evidence by transmission microscopy of weathering microsystems in soils developed from crystalline rocks. Clay Minerals, 27, 21-33.

Santiago Buey, C., Suárez Barrios, M., Garcia Romero, E., Doval Montoya, M., and Dominguez Draz, M.C. (1998) Electron microscopic study of the bentonites from "Cerro del Aguila" (Toledo, Spain). Clay Minerals, 33, 501-510.

Santos, F. (1979) Estudio geológico y edafológico del sector Montiel-Alcaraz-Bienservida (Ciudad Real-Albacete). II. Estudio edafológico. Ph.d. thesis, Universidad de Granada, Spain, $489 \mathrm{pp}$

Shimoda, S. (1971) Mineralogical studies of a species of stevensite from the Obori mine, Yamagata prefecture, Japan. Clay Minerals, 9, 185-192.

Tazaki, K. and Fyfe, W.S. (1987) Primitive clay precursors formed on feldspar. Canadian Joumal of Earth Science, 24, 506-527

Tazaki, K., Fyfe, W.S., and van der Gaast, S.J. (1989) Growth of clay minerals in natural and synthetic glasses. Clays and Clay Minerals, 37, 348-354.

Tessier, D. (1984) Etude de l'organisation des matériaux argileux. Hydration, gonflement et structuration au cours de la dessiccation et la rehumection. Ph.D. Thesis, Universite de Paris VII, Paris, $361 \mathrm{pp}$.

Tettenhorst, R. and Moore, G.E., Jr. (1978) Stevensite oolites from the Green River Formation of central Utah. Jøumal of Sedimentary Petroløgy, 48, 587-594.

van der Marel, H.W. (1976) Atlas of Infrared Spectresc $\bullet$ py of Clay Minerals and Their Admixtures. Elsevier, Amsterdam, $396 \mathrm{pp}$.

van @lphen, H. (1966) An Intreduction te Clay C•lløid

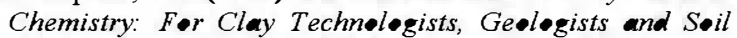
Scientists. Interscience Publishers, New York, $301 \mathrm{pp}$.

Velde, B. (1985) Clay Minerals. A Physic-Chemical Explanation of Their Occurrence. Elsevier, Amsterdam, $427 \mathrm{pp}$.

Vicente-Rodriguez, M.A., Suárez, M., Bañares-Muñoz, M.A., and López-González, J. de D. (1996) Comparative Fr-IR study of the removal of octahedral cations and stuctural modifications during acid reament of several silicates. Spectrechimic Acta, Part A, 52, 1685-1694.

E-mail of corresponding author: cristina@eucmax.sim. ucm.es 